最新のガイドラインに学ぶ|共通

\title{
最新のガイドラインに学ぶ
}

座長:金一(岩手医科大学), 渡橋 和政(高知大学),福田 幾夫(弘前大学), 大木 隆生(東京慈恵会医科大学) 2019年2月13日(水) 14:30 16:20 B会場 (岡山コンベンションセンター $2 F$ レセプションホール)

(2019年2月13日(水) 14:30 16:20 B会場)

\section{[最新-1] 最新のガイドラインに学ぶ「成人先天性心疾患診療ガイドライン」}

○市田 蕗子 (富山大学医学部)

我国の成人先天性心疾患(ACHD)患者数は, 約50万人と言われ、心筋梗塞の年間発生数を上回り, 決してまれな疾 患ではなく成人循環器疾患の 1 領域となっている。2020 年には成人患者数は小児をはるかに凌駕することが予想 されている。また、複雑心疾患術後の成人患者も増加し, 中等度以上の重症度の患者は全体の約 $1 / 3$ を占めてい る。ACHDでは、再手術や不整脈の合併などの医学的問題以外にも、就業や社会保障、心理的社会的問題など成 人特有の問題も抱えているため、生涯にわたる経過観察が必要である。

本ガイドラインは2002 年発表, 2011年に改訂, 2017年に新しい治療法や研究の動向を取り入れ全面改訂し、最 新の内容にすることを心がけた。改訂にあたって、近年の診断治療技術の急速な進歩がみられ、成人先天性心疾 患の治療や予後に変化を及ぼしている

1）肺高血圧に対する内科的治療、2）合併する不整脈に対する治療、3）カテーテル治療

4） MRIなどの診断技術に関する最新の診療情報を提供している。一方、成人先天性心疾患に特有の右心不全を来 す、体循環右室疾患（修正大血管転位など）やフォンタン循環などの血行動態や治療法に関して、最新の知見を 述べている。

また、これらの最新の診療情報の提供に加え、専門医の育成, 専門施設を中心とする診療体制の整備、小児科か ら内科への移行期医療の問題についても解説した。成人先天性心疾患の診療に当たっては、ACHDを専門とする 医師を中心とした循環器小児科, 循環器内科, 心臓血管外科, 麻酔科, 産科, 内科, 看護師, 臨床心理士などを 含む多領域、多職種によるチーム医療の診療体制を整えることが重要である。わが国においても, 専門医制度の 構築, 専門施設を中心とする診療体制の整備が進んでいる。小児科から内科への移行期医療の問題に関して も、取り組みが始まっている。

今回の改訂ガイドラインは, 臨床に即し, 幅広い領域をカバーできる実践的なものであり, 標準的な診療情報を 提供することを目標としている。成人先天性心疾患の診断法と治療法の基本と, 最新の知識と動向について概説 した。

(2019年2月13日(水) 14:30 16:20 B会場)

\section{[最新-2] 新しくなった感染症心内膜炎の予防と治療に関するガイドライン}

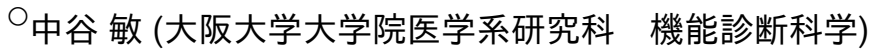

9年ぶりに日本循環器学会の感染性心内膜炎ガイドラインが改訂された。改訂に際し幾つかの工夫を行った。まず 感染性心内膜炎（IE）は集学的疾患であるため、従来通り循環器内科、心臓外科、脳血管内科の執筆者以外 に、歯科をはじめとした他領域からも多くの執筆者に参加いただいた。歯科医が参加した IEガイドラインは世界 にも類を見ないと思われる。また偏りなく文献を集め、公正にガイドラインを作成するために日本医学図書館協 会とMindsの協力を得た。さらにガイドラインの利用者の便宜を考え、最も知りたい疑問点を、広範な文献検索 の結果に基づいて以下のごとく5つのクリニカルクエスチョン（CQ）としてまとめた。

CQ1：中枢神経症状のないIE患者にも早期の MRIを提案する。

CQ2 : 10mm以上の大きな疣腫のある場合はできるだけ早い手術を推奨する。

CQ3 : 脳梗塞合併時にも IE手術を延期すべきではない。ただし脳出血時には4週間待機を提案する。 CQ4：成人における歯科治療に際し IE予防のための抗生剂投与は高度リスク例には推奨、中等度リスク例には提 案する。 
CQ5 : 小児における歯科治療に際し IE予防のための抗生剂投与は高度リスク例には推奨、中等度リスク例には提 案する。

現在、欧米のIEガイドラインでは歯科治療の際の予防的抗菌薬投与は高度リスク例に限りクラス IIaでの推奨に留 まっている。それに対し日本のガイドラインは高度リスク例には推奨、中等度リスク例には提案とより積極的な 投与をすすめている。今後のデータ蓄積が待たれる。その他、予防、画像診断の進歩、デバイス感染などにつき 最新文献に基づいて記載した。今回のガイドライン作成に際しては単なる欧米のガイドラインの追従ではな く、広い文献分析に基づいて独自の記載を行うことを心がけた。実地医家、歯家から多数のご意見をいただき今 後の改訂に備えたい。

(2019年2月13日(水) 14:30 16:20 B会場)

[最新-3] 肺血栓塞栓症および深部静脈血栓症の診断、治療、予防に関するガ イドライン

○山田 典一 (桑名市総合医療センター 循環器内科)

2018年3月に日本循環器学会を中心とした10学会の共同作業により『肺血栓塞栓症および深部静脈血栓症の診 断・治療・予防に関するガイドライン（2017年改訂版）（班長 : 伊藤正明）』が公表された。今回の改訂は8年 ぶりとなり、旧ガイドラインからは多くの重要なポイントが追加あるいは改変されることとなった。

主な改訂点としては、わが国でも使用可能となった直接作用型経口抗凝固薬を中心とした新規薬剤についてのエ ビデンスの紹介と具体的使用法などの記載、静脈血栓塞栓症の再発に影響する因子を記載、末梢型深部静脈血栓 症に対する対処法、急性肺血栓塞栓症に対する血栓溶解療法の適応の限定、下大静脈フィルターの適応の大幅な 改変とフィルターの回収・抜去の重要性の強調、弾性ストッキングの使用目的の変化、慢性血栓塞栓性肺高血圧 症に対するバルーン肺動脈形成術の有効性と適応、日本医療安全調査機構からの急性肺血栓塞栓症に係る死亡事 例の分析から出された医療事故の再発防止に向けた提言の記載などが挙げられる。こうした多くの改訂点の中か ら重要なものを選択し、改訂の根拠を含めて解説する。

(2019年2月13日(水) 14:30 16:20 B会場)

[最新-4] 新しいガイドラインからみた PAD血行再建の基本方針

駒井 宏好 (関西医科大学総合医療センター 血管外科)

近年国内外で末梢閉塞性動脈疾患（PAD）のガイドラインの発表、改訂がなされている。2015 年に米国血管 外科学会（SVS）が「下肢アテローム硬化性閉塞性動脈疾患に対する診療ガイドライン・無症候性病変および跛 行例の管理」を発表したがこれはPADの血行再建の適応をより厳密に行うよう発行されたものである。以前から TASCにも記載されているように間欠性跛行患者に対する第一選択は跛行症状の改善と生命予後改善をめざした保 存的治療であり、薬物、運動療法を中心に考えるべきことを再確認している。保存的治療に抵抗性の症例に対し ても日常生活に大きく支障をきたす患者のみ観血的血行再建（血管内治療またはバイパス術）を考慮することと されその有効性が少なくとも 2 年以上継続する見通しが50\%を超えることを最低基準として推奨している。低侵 襲とはいえ血管内治療をむやみに適応することの是非が問われている。同年、わが国でも日本循環器学会が中心 となりPADガイドラインが改訂された。この改訂版で大きく書き換えられた部分は閉塞性動脈硬化症の項であ る。間欠性跛行患者に対してはSVSガイドラインを踏襲し保存的治療を第一選択とすることが強調されてい る。特筆すべきは無症候性 PADに対してはその良好な下肢の予後を鑑み、観血的治療は控えるよう明記された点 である。また重症下肢虚血では症状や画像所見のみならず足関節や足趾動脈圧および経皮酸素飽和度、皮膚灌流 圧測定などを組み合わせ総合的に診断することが強調されている。SVSから発表された新しい重症虚血肢の指標 であるWIfl分類も記載され、これを十分考慮した上での血行再建を促している。2017 年にはヨーロッパ心臓 病学会（ESC）がヨーロッパ血管外科学会と協力し PADのガイドラインを改訂した。この改訂では特に膝下病変 の治療方針に変更があった。膝下病変への血管内治療では再狭窄率、再治療率が高く限界があることが明らかに C 日本心臓血管外科学会 
なってきており、それを受けて今回の改訂では大伏在静脈によるバイパス術が第一選択としてあげられ、しかも 推奨レベル、エビデンスレベルとも高く評価されている。循環器内科医主体の学会でありながらこのような記述 がなされていることはエビデンスを重視した合理的なガイドラインとなっていることを示している。このように 最近数年間においてもデバイスの進歩、エビデンスの蓄積などによって治療方針が変化してきている。時代の最 先端の知識をもってPADの日常診療を遂行していかなければならない。 